\title{
Teaching Behavior and Student Learning Outcomes in Dutch Mathematics Classrooms
}

Citation for published version (APA):

Tomic, W. (1989). Teaching Behavior and Student Learning Outcomes in Dutch Mathematics Classrooms. Journal of Educational Research, 82(6).

Document status and date:

Published: 01/01/1989

Document Version:

Peer reviewed version

Please check the document version of this publication:

- A submitted manuscript is the version of the article upon submission and before peer-review. There can be important differences between the submitted version and the official published version of record. People interested in the research are advised to contact the author for the final version of the publication, or visit the DOI to the publisher's website.

- The final author version and the galley proof are versions of the publication after peer review.

- The final published version features the final layout of the paper including the volume, issue and page numbers.

Link to publication

\section{General rights}

Copyright and moral rights for the publications made accessible in the public portal are retained by the authors and/or other copyright owners and it is a condition of accessing publications that users recognise and abide by the legal requirements associated with these rights.

- Users may download and print one copy of any publication from the public portal for the purpose of private study or research.

- You may not further distribute the material or use it for any profit-making activity or commercial gain

- You may freely distribute the URL identifying the publication in the public portal.

If the publication is distributed under the terms of Article $25 f a$ of the Dutch Copyright Act, indicated by the "Taverne" license above, please follow below link for the End User Agreement:

https://www.ou.nl/taverne-agreement

Take down policy

If you believe that this document breaches copyright please contact us at:

pure-support@ou.nl

providing details and we will investigate your claim.

Downloaded from https://research.ou.nl/ on date: 26 Apr. 2023 


\title{
Teaching Behavior and Student Learning Outcomes in Dutch Mathematics Classrooms
}

\author{
WELKO TOMIC
}

Open Unversity, The Netherlands

\begin{abstract}
In this articte I descnbed the means of udentifyung teaching behaviors that have cognitive and affective learning effects on students who are taking a course in mathematics 1 his study was conducted on 50 mathematies teachers who were teaching in the eighth grade. I obtained the data on teaching behaviors through direct systematic observation Multuple regression was used as the method of analysis For the cogmitive doman, the results showed that effective teachng behavcors are (a) high-level questions put to a large group of students, (b) probung, followed by a correct student response, (c) teacher wating after asking a question, (d) successful redirecting, and (e) all forms of positive acknowledgement. Effectrve teaching behaviors in the affective domain are (a) dll forms of teacher lecture/explanations, (b) probing, followed by correct student response, and (c) all forms of positive acknowledgement More teaching behaviors have a positive effect on mathematical knowledge than have a positive effect on students' attitude toward matbematics
\end{abstract}

$I^{\mathrm{n}}$ all educational activities, teachers try to realize specific learning objectives by applying more or less specific teaching behaviors In this article I identified those teaching behaviors that have possible cognitive and affective learning effects on students takıng a course in mathematics By teaching behaviors, I mean alterable behaviors belonging to the following categones teacher lecturing, explaining, and providing instructional cues, questioning, giving opportunities to respond, providing feedback, and nonacademic interdctions

I defined learning outcomes as cognitive, as well as affective, student outcomes Cognitive outcomes are reflected by the students' scores on achevement tests Affective student outcomes in this study represent scores on an attitude scale toward the subject of mathematics I examined which combination of teachung behaviors within the five different categories best predicts student learning outcomes, as measured by the average class posttest scores in the sample of 50 teachers Using multiple regressions of mathematics achievements and attıtudes of students toward mathematics for each category of teaching behaviois, I traced which linear combination of teaching behaviors explains most of the variance in student learning outcomes Also, I distungushed between teaching behaviors affecting student learning outcomes both in the cognitive and affective domains

This study is part of a wder research program that has the general objective of identifying teaching behaviors and the desired student learning outcomes in mathematics Based on the results of this study, I described possible effective teaching behaviors that I would like to apply to the development of an expermental training course in which teachers will be given directions for organizing teaching learning processes in the classroom I began this study by formulating this research question Which combination of teaching behaviors within the five categories is possibly effective in relation to student learning outcomes in the cognitive and affective domain?

\section{Method}

\section{Research Design}

To answer the above-mentioned research question, I employed a pre/postcorrelational design and observed 50 mathematics teachers, during elght lessons each, for 8 months In order to calculate statistical association measures between teaching behaviors on one side and student learning outcomes on the other, one is required to have avalable data about student learning outcomes at the end of the observation period Evidence consistently suggests, however, that cognitive student entry behavior deter-

Address correspondence to $W$ Tomic, Open University, Social Sciences Department, P O Bor 2960, 6401 DL Heerlen, 
mines to a great extent the results that students achueve after having taken a particular course (Bloom. 1976) Therefore, when investigaturg influences of teaching behaviors on student learning outcomes, one must adjust for cognitive entry behavior and affective entry characteristics of students To make adjustments regarding influences of students' cognitive entry behavior and affective entry characteristics un mathematics, pretests are indispensable

\section{Population and Sample}

The study population was composed of mathematics teachers working in the elghth grade All of the 17 selected schools used one of the following textbooks Getal en Rumte (Number and Space), Moderne Wiskunde (Modern Mathematics), or Sigma Ithe 17 schools, which could be reached by train, were drawn at random fiom schools throughout the Netherlands, within the above constraints The sample involved 50 mathematics teachers

\section{Data Collectıon Regarding Teaching Behaviors}

I obtaned the data on teaching behaviors or process variables by the direct systematic observation method and registered the stident-teacher interactions using the Five-Minute Interactions Instrument (FMI) Five welltrained observers registered the appled teaching behav 1ors in eacl classroom during five periods of 5 min a lesson, totaling eight lessons of approximately $50 \mathrm{~min}$ The length of an interaction was $5 \mathrm{~s}$ The FMI instrument was based largely on instruments developed by the Stanford Research Institute (Stallings, 1977) and is widely used in other classroom studies (Goodlad, 1984)

Using the FMI instrument, I obtaned a survey of the teaching behaviors durmg tive different 5 -mun periods of eight lessons Coding with the FMI instrument was teacher oriented I coded student behavior only when the student intelacted directly with the teacher Each mterac tion was specified by means of three codes content of the interaction, context within which the interaction occurred, and who was interacting with whom

Content The content area compriscd five categones instruction, teacher questioning, teacher giving opportunity to lespond, teacher providing feedback, and nonacademic interactions Instruction included the presentation or explanation of academic content (teacher lecturing, explaining, providing instructional cues), with or without material ands

Withon the question category, a distinction was made between questions reyurning short-term memory recall and those requiring more complex cognitive operations such as the manipulation of information previously acquired I gave a separate code to those questions allowing the expression of personal ideas feelings, or opinions Questions that the teacher redirected to another student following an unsatisfactory response were smilarly coded separately Student response codss differentiated betweer: responses produced independently and those that involucd reading from a text Any explicit indicdion that the student did not know the answer was coded as student dnes not know

Within the feedback category, codes specified whether the tcacher gave positive or negat 1 ve acknowledgcment to a student response and noted how frequently the teacher repeated or gave answers I also coded attempts to seek feedback about teacher effectiveness in explanations or clarfications Absence of teacher-student interactions durng academic tasks was coded as "slence" Nonacademic interactions wcre coded as "discuplinc," "procedure," or "social" Whencver background noise prevented the observer from hearing the content of an interaction I used the code "cannot hear"

Context One of six context codes recorded the setting for every interaction The fact that teachers may interact with varyng numbers of students was acknowledged by distrngushing among large group, small group, or pr1vate interactions "Monitoring" was the context code when the teacher supervised suidents who were working independently If the teacher was working at his or her desk and not supervising the students at ther seat work or if the leacher was interactung with someone outside of the observed class, "noninvolved" was indicated On those occasions when the teacher was observed to be di recting the students from one academic artivity to another I used the "transition" context code

Who-to-whom interactions These codes identufied who mituated the interaction and whth whom the unteraction occurred I coded tcaching behaviors as "teacher to group" and "teacher to student" in an on going interaction or "teacher to others" not withun the classroom Student bchaviors were coded as "group to tracher" and "student to tcache","

\section{Trainmg of Classroom Observe's}

Tne five classroom obscrvers were trained for 8 days, begmning with 6 consecutive days before the collection of classioom data and an additional 2 days of refresher ti duming $?$ months after the unitial traming durng the penod of classroom visuts The tranning consisted essentially of discussions familanzung the observers with the FMI instrument, followed by extonsive practice and homework in the use of the instruments The observers had to leaw the definitions of the codes and become sufficiently proficient so that a minmum of 60 interactions could bo coded accurately within a 5-min penod The training also consisted of practical exercises using videotaped and audotaped classroom situations All observeis visited classrooms for four practicc sessions to allow them to practice in a realistic setting

I began a formal check on observer agreement on the third day of traning and repeated st or subsequent days 
Toward the end of each day, the trainer compared the observers' frequencies with his or her own The research team had set the standard of comparison as a discrepancy no greater than $5 \%$ By the end of the 6 days, the five observers had achieved an acceptable level of accuracy I conducted another check on observer agreement two weeks after the training These results also were satısfactory Although 60 coded interactions per $5 \mathrm{~min}$ of classroom instruction initially seem high, this frequency could occur routmely in 5 -min periods of classroom time

\section{Interobserver Agreement and Reluablity}

I examined whether the five observers displayed any differences in coding the teaching behaviors First, from the data that they collected, I estımated the interobserver agreement between observer-pars using the parwise observation method (live observations) Two observers stmultaneously performed observations in one classroom I counted the number of codes in a specific category that each observer used and correlated these counts with one another for each category Then I performed this calculation for each of the nine observer-pairs

Second, I estimated the reliablity of observation (audio observations) by determining the internal consistency coefficient alpha (Cronbach, 1951) To do this, I worked with an additional set of data obtanned by having all observers sumultaneously code five different 5 -min fragments of an audiotaped lesson A fixed interval of $5 \mathrm{~s}$ was set between two codes, which means that the observers were forced to code after each interval of 5 min Using this interval method, I estimated the coding consistency of all five observers The context of the teaching behav1ors, however, could not be coded from the audiotapes because they lack the essentsal visual elements (See Table 1)

The results of the reliability checks can be summarized as follows The mean correlation coefficients calculated on the basis of live observations of teaching behaviors varied from - 30 (only one observer-parr) to 97 For context and who-to-whom interactions, the mean correlation coefficients varied from .72 to 90 and 75 to 85 , respectively The internal consistency coefficients of teaching behaviors calculated on the basis of audio observations varied from - 91 (once) to 99 The who-to-

Table 1 - "Who-to-Whom" Interactions Internal Consistency of Five Observers

\begin{tabular}{lcc} 
Vean & $\begin{array}{c}\text { Internal } \\
\text { correlation } \\
\text { cocfficient } \\
\text { consistency } \\
\text { coefficient } \\
\text { alpha }\end{array}$ \\
\hline Teacher to group & 96 & 99 \\
Tedcher to student & 79 & 94 \\
Student to teacher & 90 & 96 \\
Group to teacher & -22 & \\
\hline
\end{tabular}

whom interactions varied from -178 (once) to 99 Note that the coefficients for the context and the who-towhom interactions were high To a lesser extent this result also was true of teaching behaviors The above-mentroned results did not deviate from results obtained by simular research (Sirotnk, 1984) (See Table 2)

\section{Gathering Data on Student Learning Outcomes}

By student learning outcomes, I included cognitive as well as affective learning outcomes Cognitive outcomes are reffected by the students' scores on an achievement test in mathematics Affective student outcomes in this study represent the students' scores on a scale measuring attitude toward the subjects of mathematics The pretest was composed of mathematical subject matter for transition-year students (seventh grade) The pretest consisted of test items provided by the Central Institute for Test Development (CITO) For the posttest, the chosen subject matter was treated in the aforementioned eighthgrade textbooks CITO and I developed the items in the posttest Data on the variable students attitudes toward mathematics were gathered by means of a Likert scale

I provided information on the quality of the measurements for cognitive and affective student-learning outcomes and estimated the reltability of the variables in question by testing the internal consistency of the scale (the KR-20 formula) and applying Cronbach's internal consistency coefficient alpha The KR-20 for the pretest on classroom level was 87 and the KR-20 for the posttest on classroom level was 92 The internal coefficient alphas for the preattitude and postattitude scales in mathematıcs were 60 and 63 , respectively

\section{Method of Analysis, Multcollinearity and Selection Procedures}

To address the problem of multicollineanty, I followed the suggestions made by Neter and Wasserman (1974) On theoretical grounds, I reduced the number of teaching behaviors, inspected the intercorrelation matrix of the teaching behaviors in a particular model, and then removed the independent variables that produced multicollinearity To avold multicollinearity, I did not submit several of the independent vanables for analysis Instead I selected the teaching behaviors to be analyzed on conceptual grounds and on their surtability for an exper1mental teacher training program As a result of the two selection criteria, almost all of the reported teaching behaviors were composite varidbles

To reduce the number of independent vanables, I applied the backward procedure, entering the class mean scores on the cognitive, respectively affective pretest as covariables for all cases Bloom (1976) has pointed out that entering behavior explains a large part of the varnance in learning outcomes One must adjust for this confounding variable In this study, the cognitive pretest 
Table 2-Direcrly Observed Teachng Bihaviors Intumal Consastenc of He Obstrers

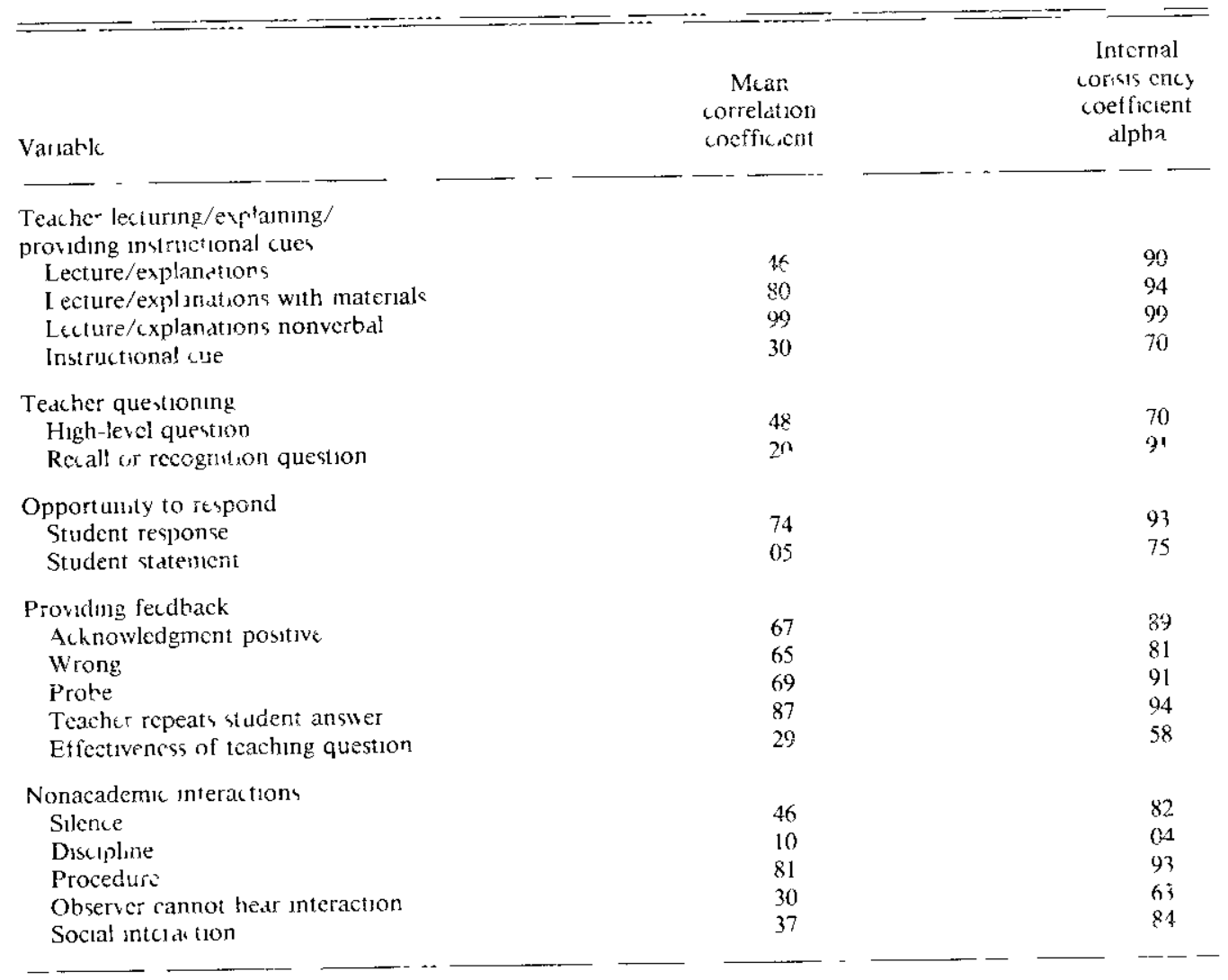

scores explained $43 \%$ of the variance in mathematics achievement and the affective pretest scores explanod $13 \%$ of the variance in the affective posttest scores

The results of the multiple regressions of the criterion variables on the independent variables are found $\mathrm{m}$ Tables 1 and 2 I cxcluded those cases where the teaching behdviors, in addition to scores on the cognutive prolest, explained less than $2 \%$ of the varance in mathematics achevement and student attutudes toward mathematics, respectively The tables report the following information rcgression coefficient $(B)$ standard crror $B$ t ratio, significance level, standardized regression coefficient (Beta) multiple coiselation cocfficicut $R$, and the determination coefticient $R^{2}$

It the following paragraphs I prescnted the results of the multiple regressions of inathematics achieveinent, re. spectively students' attitudes toward, mathematics, for different tcaching behaviors withm the disinct categories I did not, however, imply that the relationships tound reflect cause and effect Strktly controlled field experments, therefore, arc necessary The operdional defi nition of the variables is given in the Appendix

\section{Results}

\section{Results in the Cognttive Dorran}

After the multicolingarily uhcck, the tollowing three teachning bchaviors remained that explan less than 2070 of the arance in mathematurs achicvement in addition to cognitve entering behavic all forms of teacher locture/ uxplanations, lecturc/explanations to individual students and instructional cue after lecture/explanations lable 1 shows no results for behaviors that fall withm the catege-y epportumty to iespond, because they explained les than $1 \%$ of the variance in mathematics achevemont (See Table 3)

Cogniave level of questwrs Origually, the lincar reuicssion modsl consisted of the following variables student cognitive entcring behavior, recall/recognition question uit large group Together the four predutors explamed $46 \%$ of the variance in mathematics achicvement After using the backward procedure, in addition to student cognitive entening behavior, onlv the teachng hehavior, high-level question in large groun romelused in the mode: Combined with stludent copntive entcring behav1or, this teachung brhavior explained $45 \%$ of the vautance in mathematus achevement This rosult indicated that high-level oucstions in large groups describe $2 \%$ of the varunce in mathematucs achevement

froung The model included ceven predutor varables that taken together, explaned $46 \%$ of the vanance in mathematics achievenent In addition to student cognitive entry behavior, the modt liceted probing to group, high-ievel question followed by probing recall/recognition question followed by piobing probing followed by student response, probing followed by correst student re- 
sponse and probing followed by incorrect student response After analysis, two teaching behaviors remaned, namely, probing followed by student response and probing followed by correct student response

Difficulty level of questions The analysis of this model involved two predictor vanables, namely, student cognitive entering behavior and teacher waits after askıng a question, indicating the difficulty level of the teacher's question In this model, this teaching behavior apparently explained $2 \%$ of the variance in mathematics achievement

Redirecting In addition to student cognitive entering behavior, this model included the predictors redirect question and successful redirecting After I applied the backward procedure, these two teaching behaviors remained in the model and explained $4 \%$ of the variance in mathematics achievement

Student contrbution Originally the model was composed of the predictor variables student contribution, teacher response to student question, and student asks question, in addition to student cognitive entry behavior By applying the backward procedure, I eliminated two teaching behaviors and the variable student asks a question remained in the model The standardized regression coefficient of this predictor variable was negative
Providing feedback Teaching behaviors in the model belonging to the category providing feedback are teacher answer, all forms of positive acknowledgement, all forms of negative acknowledgement, and no acknowledgement after student response After analysis the behaviors, all forms of positive acknowledgement and all forms of negative acknowledgement, remained in the model and explained $4 \%$ of the variance in mathematics achievement

Nonacademic interactions In addition to student cognitive entry behavior, three teaching behaviors entered the analysis, namely, procedural interactions, discipline statement to individual student, and discipline statement to entire class After analysis, only the teaching behavior discipline statement to individual student remaned in the model and explained $4 \%$ of the variance in mathematics achievement

\section{Results in the Affective Domain}

Table 2 does not report results on teaching behaviors belonging to three categories, namely the cognitive level of questions, the difticulty of questions, and, student contribution In addition to affective entering behavior, the cxplained variance in the affective posttest scores for these categories is less than $2 \%$ (See Table 4) Table 3 -Results of Backward Multiple Regression Analysis of Mathematics Achievement on Cognituve F ntry
Behavior and Teaching Behaviors

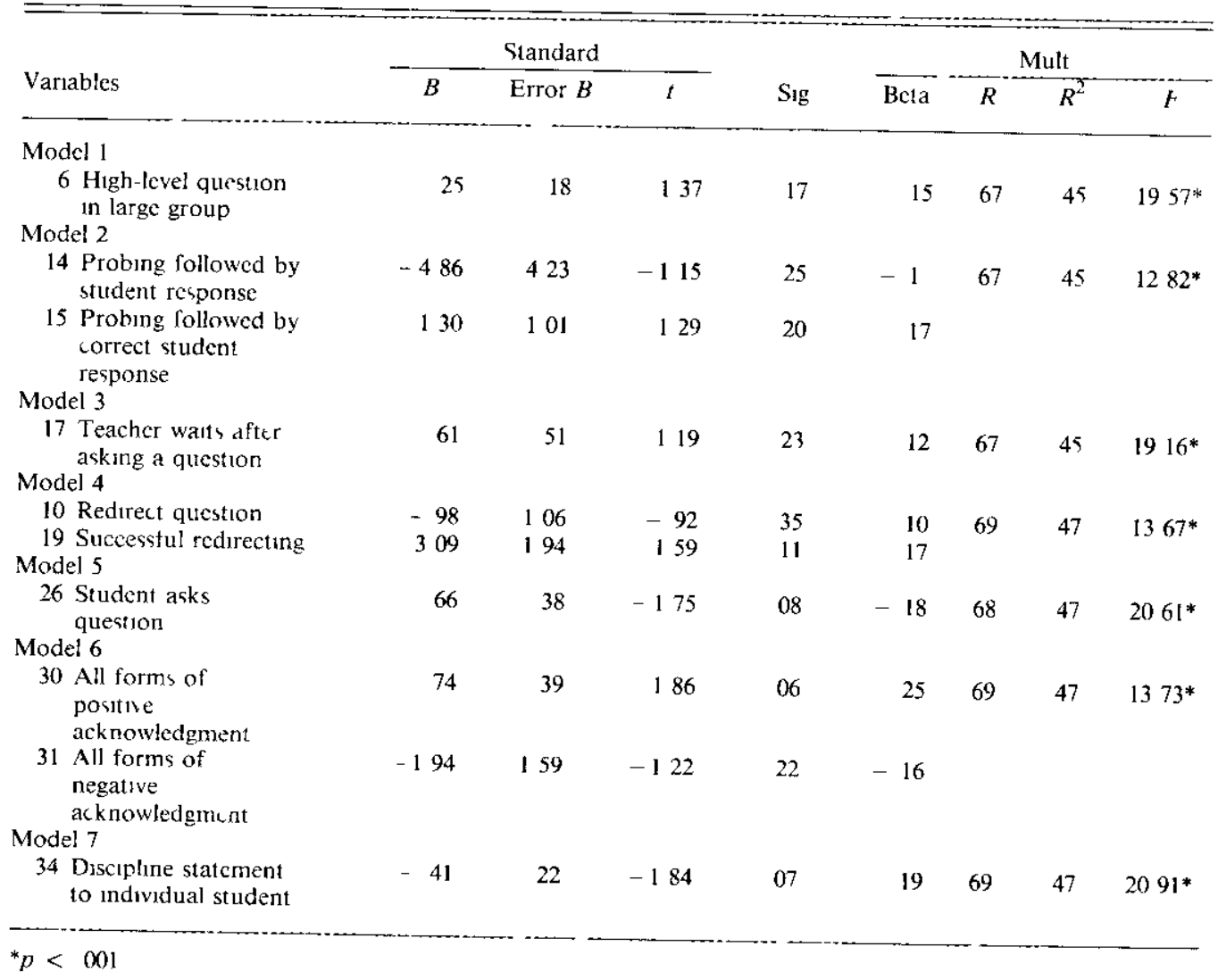




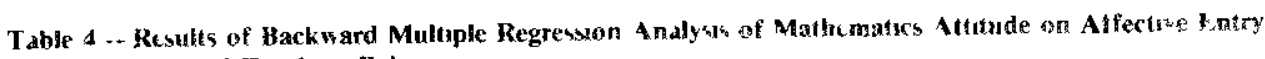
Characternstics and Teaching Behaviurs

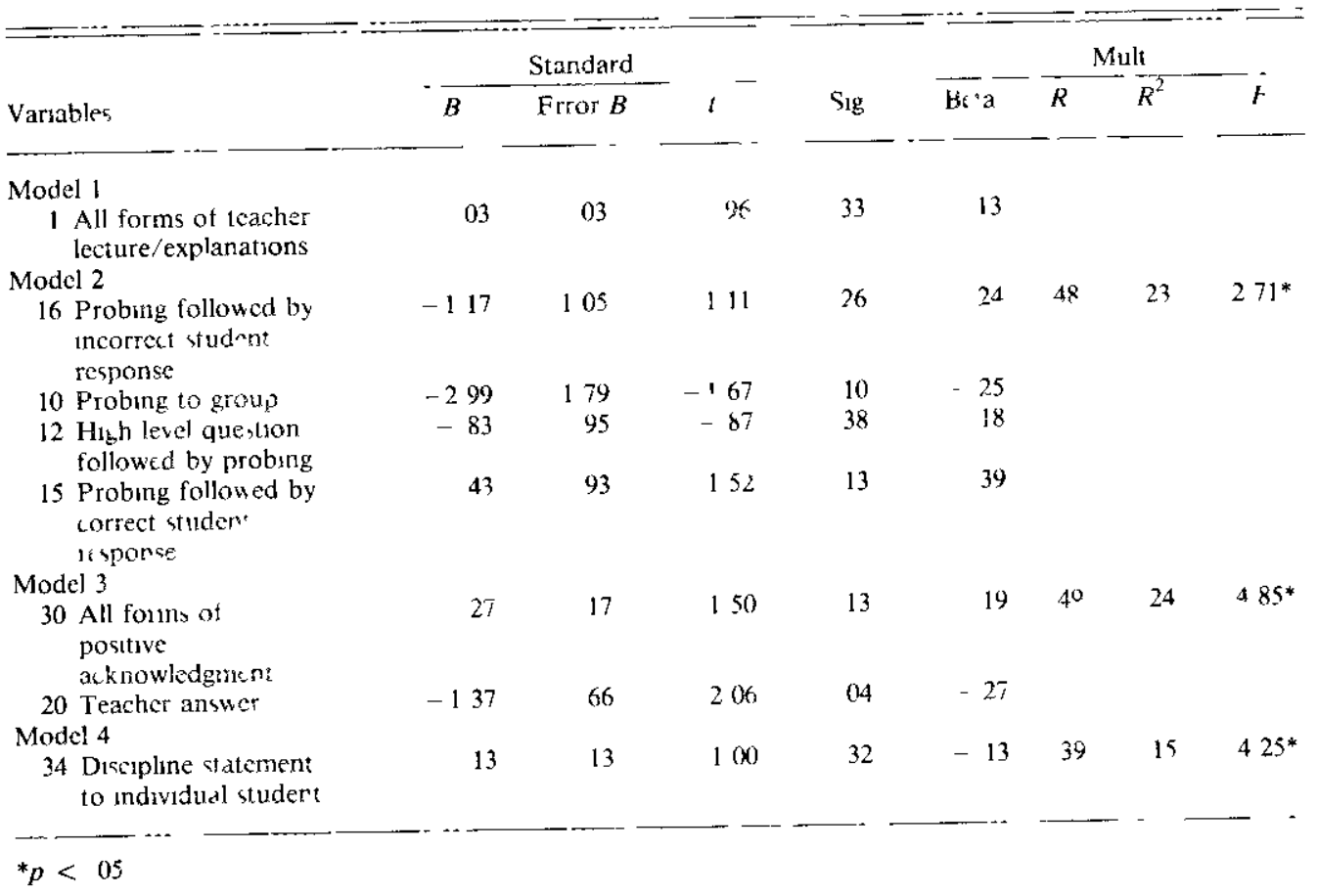

Lecturing/explaining/providing instructional cues in the model, the teaching behaviors. all forms of teacher lecture/explanations, lecture/explanations to individual student, and instructional cue after lecture/explanations, entcred the dnalysis In combination with student affec tive entry charactenstics, these predictor variables explained $16 \%$ of the variance in the affective posttest scores After I applied the backward procedure, one teaching behavior, all forms of teacher lecture/explanations, remained in the model and cxplaned $2 \%$ of the val rance in the criterion varable

Probung The model was composed of seven predktor variables The six teaching behaviors are the same as those in the probing modd in the cognitive domain Four teaching behaviors remained in the model Probing, followed by an incorrect student response, probing to group, and high-level question followed by probing had a negative relationshp with students' attitudes toward mathematics Probing followed by correct student rosponse was positively related to attitudes toward mathematics in the model

Providing feedback Hive teaching behaviors related to feedback were included in the model, namely acknowledgement positive, wrong teacher repeats student answer, tcacher answer, and etfectivcness of teaching ques tion After analysis, two teaching bchaviors explaming $11 \%$ of the val tance in students' attitudes toward mathematics remanned in the model Those teaching behaviors are all forms of positive acknowledgennent and teacher answer The regression coefficient of the latter vaulable was negative
Nonacademis interations This model included the same vartables as the model in the cognitive domain After analysis, only one teaching bchavior, discpline statcment to individua! student remaned ui the model and had a negative effect on students' attitudes toward mathcmaties

\section{Discussion}

In this article I investigated which combnation of the different teaching behaviors was most effective in pie dicting sudent learung outcomes in the cognitive and affective domain I determined the multiple regressions of mathematics achievements and the attiude of students toward mathematics for each catcgory of teaching bchaviors lif this way I traced which lincar combination of teaching bchaviors cxplains most of the ariance in studeut tearming outcomes Statements about relatıonships between teaching bchaviors on one hand and student learnung outcomcs on the other ndkate to what extent teaching bchaviors can predict lcarning outcomes

Because student sntering behavior is the most importaist predutor of student learong outcomes, I cntered student cognitive cntering behavior, respectively, student atfective entry characteristics, as the first variable in all cases in the regression model In this study, the scores on the cognitive preteat explain $43^{3 / 0}$ of the variance in matheinatics achevement and scores on the affectuve pretesi explan $13 \%$ of the variance in scores on the affective posttest

I have summalıed the results concerning posstble ef- 
fective teaching behaviors, comparing our outcomes, as far as possible, with results and/or theoretical views of other researchers Because most researchers have reported about learning outcomes in the cognitive domain, I have restricted this comparison manly to that domain In this study I also indicated some implications for the design of an experimental teacher training program

As mentioned previously in this article, I have primarly reported only composite teaching behaviors and have found that patterns of teacher-student interactions are more interestıng and significant for designing teacher trainıng programs than durectly observed, discrete teaching behaviors

In the category of teaching behaviors related to lecture, explanation, instructional cues, I observed no effect on mathematics achievement Other researchers have reported positive effects on achievement (Anderson, Evertson, \& Brophy, 1979, Bloom, 1976, Clark et al , 1979, Fisher et al , 1978, Levin, 1979, Lysakowskı \& Walberg, 1982) I found a positive effect in the affective domain, indicatmg that the more time teachers spent on lecture/ explanation, the more positive the students' attitude toward mathematıcs wll be Takıng into account that teaching behaviors related to lecture/explanation make up $36 \%$ of class time, the explaned variance is small Perhaps students find this passive activity of istening pleasant Another explanation ts that the vanable enthuslasm, a predictor of learning outcomes (Rosenshine \& Furst, 1971), leads to frequent lecturng and explaining

Within the category questioning, high-level questions had a positive effect on mathematics achievement The same effect was mentioned by Levin (1977) and Redfield and Rousseau (1980) among others In this study, I observed that questions asked a large group of students are more effective than questions asked of a small group of students Concerning the difficulty of questions, a positive effect appears to occur on mathematics achievement when a teacher waits after asking a question Obviously, insertıng a pause after asking a question contributes to learnung outcomes Maybe a correct response is more likely when students consider their answers carefully

In general, the frequency of teaching behaviors related to probing and redirectıng was low Nevertheless, I found that redirecting a question had a positive effect on mathematics achievement No positive effect on student learning outcomes was found for behaviors within the category opportunity to respond In this study, student-inttrated, task-related statements have a negative effect on learming outcomes, the same holds for the behavior student asks a question on mathematics achievement This finding contradicts the results reported by Brophy and Evertson (1974) and Good and Grouws (1975)

Because of the strong theory and the amount of research that has been carried out to date (Bloom, 1976, Fisher et al , 1978, Lysakowskı \& Walberg, 1981, 1982), I was not surprised to find that all forms of positive ac- knowledgement have a positive effect both on mathematics achievement and attitude toward mathematics I naturally observed a negative effect for all forms of negative acknowledgement Again, positive acknowledgement is apparently an effectıve teaching behavior, whereas negative acknowledgement does not contribute to learning outcomes

I found that the learning outcomes were worse for nonacademic interactions when more time was spent on the monitoring and management of learners One obvious explanation is that teachers manifesting inadequate management behavior spend a lot of tıme making discipline statements, consequently, students learn little

Regarding the influence on the future entry behavior of students, I believe, on the basis of my results on the explained variance that, in principle, teachers can change more in students' attitudes toward mathematics than they can contribute to students' knowledge of mathematics This conclusion seems important for teaching the subject, for one assumes that the more positive the attitude of students is toward mathematics, the higher they score on cognitive tests

I agree with Evertson, Emmer, and Brophy (1980) that the large number of variables related to effective teaching behavior shows its multiple facets and cannot be reduced to a single behavior Because I analyzed teaching behavIors withın behavior categories, I cannot indicate which of all observed behaviors is most important in producing achievement or positive student attitudes The applied analysis method was, therefore, inappropriate

Although these results have been observed in other process-product research (Evertson, Emmer, \& Brophy, 1980, Good \& Grouws, 1977, Rosenshıne \& Furst, 1973) I found strikingly few effective behaviors One should consider that, first, the student population had above-average achievement levels compared with other 12 - to 13-year-olds in the Netherlands and, second, that this study was conducted in highly selective schools

More teaching behaviors have a positive effect on mathematical knowledge than have a positive effect on students' attitude toward mathematıcs To appreciate the different teaching behaviors in the cognitive and affective domain, one should recognize their similanties One must not interpret these results causally, however The effectiveness of the teaching behaviors can be identified only with further research (Fenstermacher, 1976) I cannot confine this study to the results of research linking teaching behavior and student outcomes, and I agree with Gilbert and Mosteller (1972) that stnctly controlled, ecologcally valid field experiments are necessary to determine effectiveness Researchers must discover whether there is a causal connection between some teaching behaviors and a student's success at a given task Only if the answer is positive, can researchers recommend teaching behavtors that positively affect learning outcomes and const- 
tute important implicatıons for pie-and in-service teacher training

\section{RLERRE VCES}

Anderson, L M, Evertion, C M , \& Brophy, J $\Gamma$ (1979) An expen mental study of effective tcachlig in first-grade reading groups $\Gamma l e$ montary School Journal 79, 193-223

Bloom B S (1976) Human characterstus and school lecming New York McGraw-Hil]

Brophy, J E, \& Evertson ( M (1974) Process-produa $t$,orrelations in the Texas effectiveness study Iinal report Rescarch Rep No 74-4, Austun, TX Research and Development Certer for Teacher Foucation, Unversity of Fexds

Clark, M M, Gase, N L Marx, R W, Pcterson, P I Stayruok, N G, \& Wune, P H (1979) A factonal expermont on teacher structuring, soluciting, and rcacting Journal of Educational Ps,cholog, 71 , $534-552$

Cronbach L J (1951) Cotfluent alpha ard the internal structure of tesis Psickometrika, 16, 297-334

Evertson, C M , Lmmer $\Gamma$ T , \& Lruphy, J E (1980) Predu iors of effective teaching in jutior high mathematics classrooms Inurrol for Research in Mathematis Ealucatron, 11, 167-178

Fenstermacher, G A (1979) Phllesobhicd considerdion of recent research on teacher effectuveness Review of Resectich in Educ unton, 6 $157-185$

Fishtr, C W, Hibv, N A, Matrave R, Cahen, L S, Dishaw, M M, Moore, J E \& Beslincr, D C (1978) renhing behawors acadkm: learning tume and siudent achovernent Final report of phase III-B beginning teucher evaluation study ( $T_{c}(h$ Rep $\quad V-l)$ San Franusco Far West 1 dboratory for Fducational Rescarch and Deve'opment

Glbert, I P , \& Mosteller, I (1972) The urgeat need for cxpermenta tron In $\mathrm{F}$ Mostcller and $\mathrm{D} P$ Moymhan (Eds) On equality of educationat opportumt? Now York Vintage Books

Good, T L, \& Grouws, D A (1975) Process-product elationships m the Ath grade mathematcs classes Columbia, vO College of Lducation, Unwersity of Missoun

Goodtad, J (1984) 4 pla e called school New Yorh McCraw-Hill

$\mathrm{I}$ evin, $\mathrm{T}$ (1977) Trends and findmgs in classroom environment research rel-Aviv, Isrdel Suhool of Cducation, Tel Aviv Universitv

Lysakow,ky R S, \& Walber: H I (1982) Instrictional effects of cues, participation, and correstis feedback A quantitative synthessAmericun Educational Research Jounal 19, 559-578

Neter, I \& Wasserman, W (1974) Appled linear statisical models Homewood Irw'

Redfield, D I , \& Rousseau, L W (1980) A meta-analy ws of expeit mental research on tearher que tirning hehavior Tucson, $\mathrm{A} 7 \mathrm{De}$ partment of Educational Psychology, Unuversity of Arizond

Roserishine, B, \& Furst, N (1971) Research on teacher nerfornance (riteria in B O Smith (Ed) Research on teacher education, 37-72

Rosershine, B, \& Fust $N$ (1973) The use of direct observaion to study teaching In R M W Traers (Fd), Second Handbook of R:search on leaching Chuggo

Sirotrik, K A (1984) An inter-observer relabu'ty study of a modilitd SRI observation syctem Journat of Chasroom Interacion 19 , $28-38$

Stallings J A (1977) Leaming to look A handbook on classrow obscrvation and teaching models Belmont, CA Wadsworth

\section{APPENDIX}

\section{Operational Defumison of Compostt Teaching Behavions}

A Lecturmg/explanatons/instructhoral cues

1 All forms of teukher lecture/sxplanations All forms of teacher cxplanatson, including nonverbal or materially dided exther to the er ture cluss or an inclutudual stident

2 Leciure/explain to individual student All forms of texcher explaiddbrincluding nonverbal or maternally alded, to an individua' cudent 3 Instructional r ue after lecture'explan All forms of teuches explanation, to the entre clas on an individuat student tollowed $b$, an instructional cue
B Questoning

4 All forms of questions acked to enturc class All forms of ipacher questions to the entre c'as high-litel and recall or recogntion quections, questions related to the erectivencss of explanations or clurefications, isdrecied questions, prohes and asseymenta

5 All torms of questions auked to indwidual wudert Ail forms ne teacher sue entions to individual student, identicat to no 4

6 Hgh-lrvel quistion $n$ large grour Tracher high Ie tel question tu group or individual student within a group of more thdis 8 students

7 High-level question wo small group The sank as no 6 , a group of 8 or fener students

8 piccali or iecognition question in tal, "group Teacher rcall or iccognition question to group or indivdusl student wil he a group of rore than 8 atudents

9 Resal" or rewognition question in small group the same as, no 8 whbin a group of 8 or fewer stude $7^{\text {t. }}$

10 Probing group [eache- probes a rifiention in a large sroup

11 Probing andwadual student Teacher nrobes a quecilus with an individual student

12 Hy h-t tel auestion follswed by probing leduter high-level questwon 10 grour or individuat student, if followed to an incorrect stu den response, teacher cubsequently orosdes feedi) a $k$ and probes the question

13 Rewall or recogintion question fellowcd by pobmg I earbet recall or resogntion question, etc, the $5 \mathrm{~m}$ as $\mathrm{nm} 12$

14 Pigbing followed by sitident response $A^{\text {fter }}$ an incoriect stulent response to a high-lescl or recal!/rocegnitun cuestimi, the tcacher probs, the question after whin is the same sudert respond.

15 Probse followed ho correr 1 student respor, se Teacher probing tollowed by studen' resnonse, the subsaquent interating differ from redreciurg probun, negative $a$ knowledgesnen puntshment, or taacher response, $1 \mathrm{e}$, the student remouds con cils

16 robing followed h, incerrect studen respoisc Teacher probng $1^{t}$ follewed by an incorrect siudint response thaster shbequentlv provids negatue acknowledg, ment, 'cdircets, or probus

17 Teacher wdis aftor a,king a question Teater asks a (qucstion in a larse or small group followed hy silence of at least ?",

18 Studen cannot mower ouestion Teacher 2 -ks a bigh-le " 1 or recall/trognition question to a gronp̆ or an ndividual student, follewed by din incorrect studen responice or slence

19 S.ccesful redirecting I eacher redirects chesicn to donther student wherelron the student responds 1 he subsequent mecraction differs from redirect'ng probing, isceat vi achiowledgerneut punisting int or teacher tesponse $A$ coriect student response is highly probable

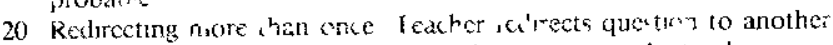
student and rectives an inc orrect studen rosp mse, the teact er negatunly at nowledges this response and once nore redirect, the same questio:

$C$ Opponunty to res,ord

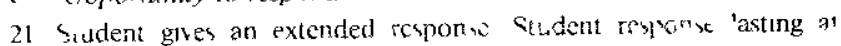
least 155

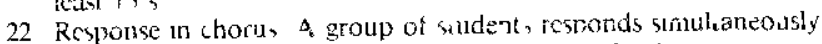

23 Siudent response followed by a ne: quection, Studunt or a group of "udert, respend, followed by a teacher rec all/reogitimn queswun or a hioti-lesel yut stion

24 Student contrihution An individual or class onumbution in the fom of explanation reading from a book, or extended response

25 Silldeil ask teachic question after 'ecilic/explanstion Teater splains 10 ind. ichal student class, followed by a student or class Guesiron to tcacher

26 Siudent asks question Student high-lavel ar recall/reogntion qusstion b. a lorgc or small group

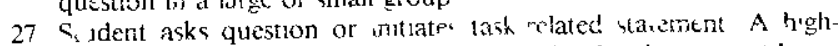
hel or recall/recognuicn questson or $x$ task-rela d satement by an Individual student or a group of ctudents

28 Tcarher responc to studerl gicsion a hugh latel of recall/ sccosnition questiun by an individual studen or a group of students, followed bu teacher rusporre

D Prowling feedbas

29 Nill forms of xhrow'zdgement ine tolkwitg torms of teacher 
feedback positive or ncgative acknowledgement, punıshment, repetituon of student answer

30 All forms of positive acknowledgement Student response followed by positive acknowledgement or teacher repctition of student response

31 All forms of negative acknowledgement Student response followed by negative acknowledgement or teacher response

32 Teacher criticizes student Teacher gives negative acknowlcdgement or punishes student
33 No acknowledgement after student response Student response, possibly incorrect, followed by a nonfeedback interaction

E Nonasademu interactions

34 Discipline statement to individual student Teacher discipline statement to individual student

35 Discipline statement to entire class Teacher discipline statement to enturc class

\section{JUST ASK}

If you want to reprint one of our articles, we can usually give you permission to do so Charges will vary, depending on your proposed use of the copyrighted materials

We will be happy to consider your request Write to Heldref Publications, Copyright and Permissions Manager, 4000 Albemarle Street, NW, Washıngton, DC 20016, or call (202) 362-6445 